\title{
Partisipasi laki-laki dalam program Keluarga Berencana di era masyarakat postmodern
}

\section{Men's participation in family planning program in the postmodern society era}

\author{
Sutinah \\ Departemen Sosiologi, Fakultas Ilmu Sosial dan Ilmu Politik \\ Universitas Airlangga \\ E-mail: tina_bth@yahoo.com, tinafisip07@gmail.com \\ Telepon: 081330431600
}

\begin{abstract}
This study is motivated by the low number of men who become KB acceptor, although family planning programs have been promoted in Indonesia since the 1970s. Therefore, this study aims to examine: (1) men's participation in the implementation of Family Planning Program in East Java Province; (2) obstacles that impede the participation of men in the implementation of the Family Planning Program; And (3) Strategies that need to be developed to increase men's participation in the implementation of family planning programs in the postmodern society. This study was conducted in Surabaya which was choosen for representing the urban and Madiun for representing the character of rural communities. Samples was choosen in each city/district consists of 75 people or a total of 150 men. Data was collected through structured interviews with 15 informants are underwent indepth interview. This study found that (1) male participation in family planning in particular the use of vasectomy methods is still very low in both Surabaya and Madiun, most EFAs place family planning programs as women's responsibilities; (2) obstacles that impede the participation of men in family planning are psychological constraints such as concern in decreasement in masculinity, impotence, social constraints; and the constraints that come from the wife such as possibility of wife's affair; and (3) strategies for increasing men's participation in family planning include more intensive socialization, and mass media campaigns, which feature popular ad stars, so the participation of men in the Family Planning Program is no longer considered something which is taboo or embarrassing.
\end{abstract}

Keywords: Family planning program, family planning participation, vasectomy

\begin{abstract}
Abstrak
Studi ini dilatarbelakangi oleh masih rendahnya laki-laki yang menjadi akseptor KB, meskipun program KB telah digalakkan sejak tahun 1970-an. Oleh karena itu, studi ini bertujuan untuk mengkaji: (1) Partisipasi kaum laki-laki dalam pelaksanaan Program KB di Provinsi Jawa Timur; (2) Kendala-kendala yang menghambat partisipasi kaum laki-laki dalam pelaksanaan Program KB; dan (3) Strategi yang perlu dikembangkan untuk meningkatkan partisipasi kaum laki-laki dalam pelaksanaan Program KB di era masyarakat postmodern. Studi ini dilakukan di Kota Surabaya yang mewakili masyarakat perkotaan dan Kabupaten Madiun yang mewakili karakteristik masyarakat pedesaan. Sampel pada masing-masing kota/kabupaten sebanyak 75 orang atau seluruhnya berjumlah 150 orang laki-laki, yang dipilih secara sengaja (purposif). Pengumpulan data dilakukan dengan wawancara terstruktur, selain itu masing-masing daerah dipilih 15 informan yang diwawancarai secara mendalam (in-depth interview). Studi ini menemukan sebanyak satu (1) partisipasi laki-laki dalam ber KB khususnya penggunaan metode vasektomi masih sangat rendah baik di Surabaya maupun Madiun, sebagian besar Pasangan Usia Subur (PUS) menempatkan Program KB sebagai urusan dan tanggung jawab kaum perempuan; (2) kendala yang menghambat partisipasi laki-laki dalam ber-KB adalah kendala psikologis (kekhawatiran akan menurunnya kejantanan, impotensi), kendala sosial (malu jadi pergunjingan); dan kendala yang datang dari istri (memudahkan terjadinya perselingkuhan); dan (3) strategi untuk meningkatkan partisipasi laki-laki dalam ber-KB antara lain perlu dilakukan sosialisasi yang lebih intensif, dan kampanye melalui media massa, yang menampilkan bintang iklan yang populer, sehingga keikutsertaan laki-laki dalam Program KB tidak lagi dianggap sebagai sesuatu yang tabu atau memalukan.
\end{abstract}

Kata kunci: program KB, partisipasi ber-KB, vasektomi

\section{Pendahuluan}

Di era postmodern, salah satu upaya yang dikembangkan pemerintah untuk meningkatkan efektivitas pelaksanaan Program KB adalah melibatkan dan mendorong peran aktif kaum laki-laki dalam mengatur kehamilan dan kelahiran demi kesejahteraan keluarganya. Sejak tahun 1999 Program KB perhatian besar terhadap keikutsertaan kaum laki-laki sudah digagas dan dimulai. Sebelumnya, 
perhatian dan pelaksanaan Progam KB cenderung lebih difokuskan pada kaum perempuan, sehingga ada kesan bahwa KB adalah urusan dan tanggung jawab kaum perempuan. Data Survey Demografi dan Kesehatan Indonesia (SDKI) 2002-2003, menunjukkan bahwa di kalangan perempuan pemakaian kontrasepsi sebesar 98,7 persen, sedangkan untuk kontrasepsi laki-laki hanya 1,3 persen. Bahkan data yang dikeluarkan oleh Pusat Data Informasi Kesementerian Republik Indoneia pada tahun 2014 menunjukkan bahwa jumlah KB laki-laki hanya mencapai 1,81\% (Kementerian Kesehatan RI 2014).

Berdasarkan SDKI 2002/2003, keikutsertaan laki-laki dalam program KB tercatat sebesar 4,4 persen, terdiri dari penggunaan kontrasepsi modern sebesar 1,3 persen, yaitu kondom $(0,9$ persen $)$ dan vasektomi $(0,4$ persen), sedangkan penggunaan kontrasepsi tradisional sebesar 3,1 persen, seperti senggama terputus (1,5 persen) dan pantang berkala (1,6 persen). Hingga tahun 2010, meski tidak ada data yang pasti tentang keikutsertaan kaum laki-laki dalam Program KB, tetapi disinyalir tidak ada perubahan yang berarti, karena masih ada berbagai kendala, baik secara kultural, psikologi, ekonomi, maupun sosial yang sifatnya tak jarang kontra-produktif. Di berbagai komunitas, masalah KB dan kesehatan reproduksi masih dipandang sebagai tanggung jawab perempuan. Pengetahuan dan kesadaran laki-laki dan keluarga mengenai KB masih relatif rendah. Selain itu, ada keterbatasan penerimaan dan aksesibilitas pelayanan kontrasepsi laki-laki.

Pengetahuan masyarakat kota maupun desa terhadap program KB belum berkembang secara optimal, meski dari segi pendidikan masyarakat kota pada umumnya lebih maju dari masyarakat pedesaan. Pengetahuan yang keliru dan kurang terhadap Program KB, misalnya tentang vasektomi yang dalam beberapa hal ditakutkan akan bisa menyebabkan impoten, sedangkan penggunaan kondom di sebagian besar kaum laki-laki dianggap dapat mengurangi kenikmatan dalam hubungan seksual, merepotkan, dan dipersepsikan hanya untuk penderita atau mencegah penyakit kelamin dan HIV/ AIDS saja. Berbagai persepsi keliru seperti ini yang menyebabkan partisipasi kaum laki-laki dalam program $\mathrm{KB}$ menjadi sangat terbatas.

Untuk meningkatkan peran kaum laki-laki dalam Program KB, dalam beberapa tahun terakhir berbagai upaya telah dicoba dilakukan pemerintah. Pendekatan yang diterapkan pemerintah dalam meningkatkan peran laki-laki dalam KB dan kesehatan reproduksi adalah menempatkan laki-laki agar dapat memperoleh informasi tentang KB yang benar. Peran laki-laki dalam KB diharapkan bukan sekadar sebagai peserta $\mathrm{KB}$ pasif atau sekadar mendukung pasangan menggunakan alat kontrasepsi tertentu, melainkan diharapkan kaum laki-laki juga berperan dalam kesehatan reproduksi, antara lain membantu mempertahankan dan meningkatkan kesehatan ibu hamil, merencanakan persalinan aman oleh tenaga medis, menghindari keterlambatan dalam mencari pertolongan medis, membantu perawatan ibu dan bayi setelah persalinan, menjadi ayah yang bertanggung jawab, mencegah penularan penyakit menular seksual, menghindari kekerasan terhadap perempuan, serta tidak bias gender dalam menafsirkan kaidah agama, termasuk bersedia menggunakan kontrasepsi bagi kaum laki-laki.

Dengan terjadinya peningkatan partisipasi laki-laki diharapkan dalam jangka pendek maupun jangka panjang dapat meningkatkan derajat kesehatan ibu, bayi dan anak, menurunkan angka kematian ibu dan bayi, mencegah dan menanggulangi infeksi saluran reproduksi serta penyakit menular seksual. Beberapa permasalahan yang dikaji dalam kegiatan ini adalah: (1) Bagaimana gambaran tentang partisipasi kaum laki-laki dalam pelaksanaan Program KB di Provinsi Jawa Timur? Termasuk di sini, bagaimana pandangan kaum laki-laki sebagai bagian dari kelompok masyarakat postmodern terhadap tanggungjawab keluarga (suami-istri) dalam pelaksanaan Program KB?; (2) Kendala-kendala apa sajakah yang menghambat partisipasi kaum laki-laki dalam pelaksanaan Program KB di Provinsi Jawa Timur? Termasuk di sini, sejauh mana ideologi patriarkhis menjadi penghambat partisipasi kaum laki-laki dalam pelaksanaan Program KB?; dan (3) Strategi apakah yang perlu dikembangkan untuk meningkatkan partisipasi kaum laki-laki dalam pelaksanaan Program KB di Provinsi Jawa Timur di era masyarakat postmodern? 
Sejak program KB dicanangkan tahun 1970-an, sampai saat ini partisipasi kaum laki-laki sangat rendah, sehingga dikhawatirkan di tahun-tahun mendatang bukan tidak mungkin laju pertumbuhan penduduk akan lebih sulit dikendalikan dan kesejahteraan keluarga lebih sulit diwujudkan lika pelaksanaan dan tanggung jawab Program KB hanya dibebankan kepada kaum perempuan. Studi tentang partisipasi laki-laki dalam pelaksanaan program KB ini penting dilakukan untuk menemukan alasan dan kendala kaum laki-laki kurang berpartisipasi dalam program $\mathrm{KB}$, untuk itu diharapkan hasil penelitian ini dapat dirumuskan strategi dan program untuk meningkatkan partisipasi kaum laki-laki dalam pelaksanaan Program KB di Provinsi Jawa Timur

\section{Metode Penelitian}

Studi ini bertujuan untuk memetakan situasi problematik yang timbul dalam pelaksanaan program KB yang melibatkan dukungan aktif laki-laki dan untuk merumuskan strategi dan program untuk meningkatkan peran kaum laki-laki dalam pelaksanaan program KB. Studi ini mencoba menggabungkan tipe penelitian survey dan studi kualitatif yang mendalam. Penelitian ini dilakukan dilakukan di dua kota/kabupaten, yaitu: di Kota Surabaya dan Kabupaten Madiun. Kota Surabaya dipilih untuk mewakili karakteristik masyarakat perkotaan, sedangkan Kabupaten Madiun dipilih untuk mewakili karakteristik masyarakat pedesaan.

Teknik pengumpulan data dilakukan dengan dua tahap. Pertama, mengumpulkan data sekunder tentang penduduk dan perkembangan pelaksanaan Program KB di Provinsi Jawa Timur yang tersedia di Bappeda, BPS dan Badan Pemberdayaan Masyarakat Provinsi Jawa Timur. Pemaparan dan analisis terhadap data sekunder ini penting dilakukan untuk mengetahui peta makro permasalahan kependudukan dan Program KB di Provinsi Jawa Timur. Kedua, mengumpulkan data primer yang dilakukan di lokasi-lokasi di Provinsi Jawa Timur, dengan wawancara terstruktur menggunakan seperangkat kuesioner. Selain wawancara terstruktur, studi ini juga melakukan wawancara mendalam pada sejumlah informan guna menggali data secara mendalam, terutama untuk data yang tidak dapat diperoleh melalui wawancara terstruktur.

Responden yang diwawancarai adalah kaum laki-laki atau suami yang ditetapkan sebanyak 150 orang, untuk masing-masing daerah sebanyak 75 responden yang dipilih secara purposif (sengaja) pada pasangan usia subur (PUS) yang akseptornya laki-laki atau suami. Informasi yang digali difokuskan pada situasi problematik yang dihadapi kaum laki-laki dalam menyikapi Program KB. Dari 150 responden yang diteliti, untuk masing-masing daerah ditetapkan 15 informan yang akan diwawancarai secara mendalam (in-depth interview) untuk menggali data yang lebih menukik agar dapat memperjelas persoalan yang tengah dikaji.

Data yang berhasil dikumpulkan, baik primer maupun sekunder, diolah setelah sebelumnya dilakukan editing untuk menyaring data yang benar-benar valid. Seluruh data hasil studi ini sudah barang tentu tidak ditampilkan mentah-mentah, tetapi diolah dan ditampilkan data dalam bentuk yang ringkas dengan harapan agar lebih mudah dipahami pembaca dan memperjelas analisis. Interpretasi dilakukan dengan mendiskusikan antara temuan dan teori atau hasil penelitian sebelumnya.

Setelah dianalisis dan diinterpretasi dengan teori-teori yang digunakan, maka selain dirumuskan kembali ringkasan atau temuan-temuan pokok, juga dikemukakan langkah-langkah strategis untuk mendorong peningkatan peran kaum laki-laki dalam pelaksanaan Program KB di Provinsi Jawa Timur.

\section{Hasil dan Pembahasan}

Upaya untuk membatasi jumlah kelahiran dan mengatur jarak kelahiran anak, termasuk program yang berupaya melibatkan partisipasi kaum laki-laki dalam kegiatan KB sesungguhnya adalah bagian dari kebijakan antinatal. Kebijakan antinatal adalah kebijakan yang dikembangkan negara dan pemerintah untuk membatasi dan mengatur kelahiran dengan tujuan untuk meningkatkan kesejaheraan keluarga. 
Di beberapa Negara (China dan India misalnya), pemerintah berusaha membatasi jumlah penduduk dengan berbagai cara, antara lain: (1) menyediakan fasilitas kontrasepsi, aborsi, sterilisasi dan menunjang penggunaannya, (2) memberikan sanksi bagi keluarga besar, dan sebaliknya memberikan imbalan bagi keluarga kecil (Hariastuti 2000).

Di India, misalnya, selama beberapa tahun pemerintah telah menerapkan kebijakan membayar para laki-laki yang bersedia melakukan vasektomi (Bird 1976). Sementara itu, di Taiwan, pemerintah juga memberikan imbalan uang bagi keluarga yang membatasi jumlah anggota keluarganya (Yen et al. 1973). Di Singapura, pemerintah dikenal sangat berhasil menurunkan tingkat kelahiran dengan cara memberikan aneka ragam tunjangan yang meliputi biaya persalinan yang besarnya bervariasi menurut urutan kelahiran, pemotongan pajak penghasilan untuk keluarga yang memiliki tiga orang anak, dan prioritas bantuan perumahan bagi mereka yang mempunyai dua anak atau kurang (Kee \& Lee, 1973). Kebijakan antinatal, baik yang mengancamkan sanksi maupun yang berupa pemberian insentif, intinya bertujuan untuk melakukan regulasi terhadap pengaturan jumlah dan jarak kelahiran anak.

Program KB tidak hanya tanggung jawab dan urusan perempuan, tetapi merupakan tanggung jawab bersama keluarga. Arti penting melibatkan dan mendorong keterlibatan kaum laki-laki dalam Program KB sesungguhnya bukan hanya sebagai bentuk atau ekspresi dari tumbuhnya kesetaraan gender di kalangan masyarakat Kota Surabaya dan Kabupaten Madiun, tetapi sekaligus juga merupakan langkah taktis untuk meningkatkan keberhasilan program pengendalian jumlah penduduk.

Studi ini menghasilkan beberapa temuan pokok sebagai berikut: Pertama, hampir separuh (47 persen) responden (laki-laki/suami) tidak pernah mengikuti sosialisasi/penyuluhan Program Keluarga Berencana (KB), sebanyak 44 persen responden jarang mengikuti sosialisasi; dan hanya sebagian kecil (9 persen) responden (laki-laki/suami) yang mengikuti sosialisasi tentang program KB. Alasan responden tidak pernah dan jarang mengikuti penyuluhan karena sibuk dan menganggap penyuluhan Program KB menjadi urusan perempuan.

Kedua, sebagian besar ( 89 persen) responden mengetahui kondom sebagai alat/metode kontrasepsi yang digunakan oleh laki-laki/suami. Sebaliknya sebagian besar responden (laki-laki/suami) tidak mengetahui adanya metode kontrasepsi yang disebut dengan pantang berkala (71 persen), sedangkan vasektomi sebagai metode kontrasepsi hanya diketahui oleh 39 persen responden (laki-laki/suami).

Tabel 1.

Metode kontrasepsi yang diketahui

\begin{tabular}{lcccccc}
\multirow{2}{*}{ Metode } & \multicolumn{6}{c}{ Jumlah } \\
\cline { 2 - 7 } & \multicolumn{2}{c}{ Tahu } & \multicolumn{2}{c}{ Tidak tahu } & \multicolumn{2}{c}{ Total } \\
\cline { 2 - 7 } & Frekuensi & Persen & Frekuensi & Persen & Frekuensi & Persen \\
\hline Kondom & 133 & 89 & 17 & 11 & 150 & 100 \\
\hline Pantang berkala & 43 & 29 & 107 & 71 & 150 & 100 \\
\hline Vasektomi & 58 & 39 & 92 & 61 & 150 & 100
\end{tabular}

Sumber: data primer

Ketidaktahuan responden tentang vasektomi, ternyata bukan hanya mengenai perbedaannya dengan tubektomi, tetapi sebanyak 80 persen dari seluruh responden juga tidak dan kurang tahu tentang kemungkinan resiko yang terjadi bila menggunakan kontrasepsi vasektomi, bahkan hanya sebagian kecil (12 persen) responden yang mengetahui manfaat kontrasepsi vasektomi. Pada umumnya responden juga tidak megetahui tempat layanan $\mathrm{KB}$ vasektomi, sepengetahuan responden layanan KB hanya diperuntukkan bagi perempuan. 
Tabel 2.

Pengetahuan mengenai vasektomi

\begin{tabular}{lcccccccc} 
& \multicolumn{8}{c}{ Jumlah } \\
\cline { 2 - 9 } Informasi & \multicolumn{2}{c}{ Tahu } & \multicolumn{2}{c}{ Kurang tahu } & \multicolumn{2}{c}{ Tidak tahu } & \multicolumn{2}{c}{ Total } \\
\cline { 2 - 9 } & Frekuensi & Persen & Frekuensi & Persen & Frekuensi & Persen & Frekuensi & Persen \\
\hline $\begin{array}{l}\text { Perbedaan } \\
\text { dengan } \\
\text { tubektomi }\end{array}$ & 33 & 22 & 60 & 40 & 57 & 38 & 150 & 100 \\
\hline $\begin{array}{l}\text { Resiko } \\
\text { yang } \\
\text { mungkin } \\
\text { terjadi }\end{array}$ & 30 & 20 & 61 & 41 & 59 & 39 & 150 & 100 \\
\hline $\begin{array}{l}\text { Manfaat } \\
\text { yang } \\
\text { diperolah }\end{array}$ & 18 & 12 & 58 & 39 & 74 & 49 & 150 & 100 \\
\hline $\begin{array}{l}\text { Tempat } \\
\text { layanan KB } \\
\text { tuberktomi }\end{array}$ & 28 & 19 & 53 & 35 & 69 & 46 & 150 & 100 \\
\hline Biaya & 30 & 20 & 46 & 31 & 74 & 49 & 150 & 100
\end{tabular}

Sumber: data primer

Ketiga, 17 persen responden dengan tegas mengatakan bahwa KB laki-laki itu tabu. Selain itu ada sebanyak 22 persen responden (laki-laki/suami) menyatakan bahwa program KB laki-laki itu beresiko bagi potensi (kemampuan) seksual kaum laki-laki, terutama untuk kontrasepsi vasektomi. Banyaknya kaum laki-laki yang beranggapan setelah menggunakan vasektomi akan kehilangan kejantanannya, terjadi impotensi dan adanya persepsi yang salah, serta pandangan yang negatif bahwa vasektomi itu sama dengan pengebirian, menjadikan laki-laki enggan untuk menjalani vasektomi.

Keempat, di kalangan keluarga, baik di lingkungan kota besar maupun kota menengah, partisipasi kaum laki-laki dalam program KB secara umum relatif masih sangat rendah. Dari 150 PUS yang diteliti, sebagian besar PUS umumnya mempergunakan kontrasepsi metode suntik sebanyak 37 persen, pil (23 persen), tubektomi (13 persen), minum ramuan tradisional (4 persen) dan IUD (9 persen) -yang semua itu adalah metode ber-KB yang dilakukan kaum perempuan. Hanya satu (1 persen) PUS yang mengaku melakukan vasektomi dalam ber-KB. Terlepas metode KB yang dipilih, secara keseluruhan, baik di Surabaya maupun Madiun, sebagian besar PUS umumnya masih Program KB sebagai urusan dan tanggungjawab kaum perempuan (Sriudayani 2003).

Berkaitan dengan temuan tersebut, metode kontrasepsi yang dinilai paling disukai atau dinilai paling nyaman, aman dan sangat efektif dalam mencegah terjadinya kehamilan adalah suntik, pil dan tubektomi. Selain itu, penelitian ini juga menemukan sebanyak 11 persen responden mengaku penggunaan kondom dinilai paling aman dan efektif. Dengan demikian, bahwa paktek KB sesungguhnya telah melibatkan pihak perempuan dan laki-laki, tetapi secara persentatif masih terlihat jelas bahwa dalam prakteknya program KB masih lebih banyak dilakukan oleh kaum perempuan. Bagi PUS yang masih belum lama menikah dan masih merencanakan untuk memiliki anak lagi, mereka umumnya menyatakan metode kondom (11 persen) dan pantang berkala ( 3 persen), paling aman karena metode kontrasepsi yang bagus dinilai bisa membuat istri mereka tidak lagi bisa hamil.

Sebagian besar keluarga pada umumnya mengaku memutuskan secara bersama antara suami dan istri tentang metode kontrasepsi yang digunakan, dan pemilihan petugas layanan KB. Meskipun demikian, ada sejumlah responden laki-laki yang tidak mengijinkan jika istri mereka memasang alat kontrasepsi, seperti IUD pada dokter laki-laki. 
Kelima, berkaitan dengan kesediaan laki-laki untuk ber-KB, studi ini menemukan sebanyak 14 persen responden bersedia tanpa syarat. Sementara itu, sebanyak 34 persen responden menyatakan bersedia, asal ada alasan yang kuat yang mendukung keputusan mereka, seperti istrinya tidak memungkinkan ber-KB karena alasan kesehatan atau istri menghadapi resiko ketika ber KB. Temuan ini tidak beda dengan apa yang dikemukakan oleh Wetson (2002). Sebanyak 31 persen responden bahkan menyatakan tidak bersedia melakukan vasektomi dengan alasan apa pun, karena mereka menganggap vasektomi lebih banyak kerugiannya daripada manfaatnya. Selebihnya responden (lakilaki) mengatakan bersedia menggunakan metode kontrasepsi laki-laki mantap (vasektomi) jika metode tersebut tidak memberikan dampak apapun terhadap diri mereka.

Temuan tersebut diperkuat dengan data yang diperoleh, yaitu hampir separuh responden (46 persen) merasa bahwa memakai metode kontrasepsi adalah urusan dan tanggung jawab kaum perempuan. Selain itu, tidak sedikit responden yang menyatakan bahwa tidak bersedia melakukan vasektomi karena alasan ekonomi. Mereka khawatir dengan vasektomi memerlukan biaya yang cukup besar sehingga tidak mampu membiayai. Alasan lain yang terungkap mengapa responden enggan untuk melakukan vasektomi karena merasa takut dengan efek samping yang ditimbulkannya.

Keenam, secara umum studi ini menemukan ada berbagai kendala yang menghambat kemungkinan kaum laki-laki untuk ber-KB mantap alias melakukan vasektomi. Sebagian besar responden (lakilaki) menyatakan sangat khawatir jika melakukan vasektomi dapat mempengaruhi kejantanan kaum laki-laki sebagaimana dikemukakan oleh 36 persen responden. Sebanyak 26 persen responden mengaku malu, karena dikhawatirkan akan membuat mereka menjadi bahan pergunjingan lingkungan sosialnya. Selain itu, dengan melakukan vasektomi, sebanyak 36 persen responden juga khawatir dengan vasektomi akan mempersulit mereka jika ingin mencabut vasektomi yang dilakukan ketika mereka ingin punya anak lagi.

Selain kendala sebagaimana dikemukakan oleh responden laki-laki, studi juga menemukan bahwa tidak sedikit istri yang tidak setuju apabila suaminya melakukan vasektomi. Alasannya, sebanyak 57 persen istri responden menyatakan bahwa vasektomi akan membuka peluang laki-laki selingkuh dengan aman, salah satu kelemahan laki-laki adalah mudah tergoda oleh perempuan lain, dan bukan tidak mungkin melakukan perselingkuhan. Dengan melakukan vasektomi, dikhawatirkan akan membuat laki-laki seolah-olah lebih bebas, minimal akan tercitra sebagai laki-laki yang "amanaman" saja jika melakukan perselingkuhan, karena tidak mungkin pasangannya hamil. Sebanyak 56 persen responden (laki-laki) mengemukakan sangat setuju dan setuju jika metode kontrasepsi vasektomi itu secara ekonomi mahal. Responden tidak/belum menyadari dan mengetahui kelebihan metode kontrasepsi mantap bagi kaum laki-laki ini, antara lain, lebih praktis, lebih aman dan lebih murah, karena sekali pakai dapat untuk jangka waktu tertentu.

Diakui bahwa peran dan keterlibatan kaum laki-laki dalam program KB sangat penting, tetapi studi ini menemukan bahwa partisipasi laki-laki dalam program KB masih rendah, bahkan laki-laki masih beranggapan bahwa laki-laki yang ber KB itu tabu dan berisiko terhadap potensi seksual laki-laki. Rendahnya partisipasi laki-laki dalam program KB terutama metode vasektomi, ternyata juga karena banyak (57 persen) istri yang tidak menghendaki suaminya menggunakan metode vasektomi karena membuka peluang laki-laki untuk berselingkuh dan mudah tergoda perempuan lain. Akan tetapi jika alasan kesehatan istri, laki-laki (suami) bersedia mengikuti program KB mantap dengan menggunakan vasektomi. Oleh sebab itu memberikan sosialisasi tentang pengertian vasektomi, proses vasektomi, keuntungan dan kerugian penggunaan metode kontrasepsi mantap bagi laki-laki serta berbagai hal yang berkait dengan persoalan vasektomi kiranya sangat dibutuhkan untuk menguatkan semangat para laki-laki untuk berpartisipasi dalam program KB laki-laki khususnya vasektomi. 
Tabel 3.

Kerugian Mengikuti Program KB Pria (Vasektomi)

\begin{tabular}{|c|c|c|c|c|c|c|c|c|c|c|}
\hline \multirow{3}{*}{ Kerugian } & \multicolumn{10}{|c|}{ Jumlah } \\
\hline & \multicolumn{2}{|c|}{$\begin{array}{l}\text { Sangat } \\
\text { setuju }\end{array}$} & \multicolumn{2}{|c|}{ Setuju } & \multicolumn{2}{|c|}{$\begin{array}{l}\text { Kurang } \\
\text { setuju }\end{array}$} & \multicolumn{2}{|c|}{ Tidak setuju } & \multicolumn{2}{|c|}{ Total } \\
\hline & frekuensi & persen & frekuensi & persen & frekuensi & persen & frekuensi & persen & frekuensi & persen \\
\hline $\begin{array}{l}\text { Mempengaruhi } \\
\text { kenjantanan pria }\end{array}$ & 54 & 36 & 47 & 31 & 39 & 26 & 10 & 7 & 150 & 100 \\
\hline $\begin{array}{l}\text { Membuka peluang pria } \\
\text { selingkuh dengan aman }\end{array}$ & 39 & 26 & 47 & 31 & 47 & 31 & 17 & 11 & 150 & 100 \\
\hline $\begin{array}{l}\text { Bisa menjadi bahan } \\
\text { pergunjingan orang }\end{array}$ & 13 & 9 & 25 & 17 & 86 & 57 & 26 & 17 & 150 & 100 \\
\hline $\begin{array}{l}\text { Beresiko jika direhabilitasi } \\
\text { sulit kembali normal }\end{array}$ & 52 & 35 & 54 & 36 & 27 & 18 & 17 & 11 & 150 & 100 \\
\hline Secara ekonomi mahal & 38 & 25 & 47 & 31 & 51 & 34 & 14 & 9 & 150 & 100 \\
\hline Merepotkan/tidak praktis & 22 & 15 & 47 & 31 & 66 & 44 & 15 & 10 & 100 & 100 \\
\hline
\end{tabular}

Sumber: data primer

Menurut Chin \& Benne (1989) secara garis besar ada beberapa metode yang dapat dikembangkan untuk untuk mempengaruhi perubahan perilaku masyarakat, yaitu: (1) rasional-empiris, (2) normatifedukatif, dan (3) paksaan-kekuasaan.

Strategi pertama berasumsi bahwa manusia adalah rasional dan mereka akan menuruti keputusan mereka sendiri bila keputusan itu ditunjukkan kepada mereka. Strategi normatif-edukatif sebetulnya juga berasumsi bahwa manusia adalah rasional, tetapi mengakui bahwa manusia bertindak berdasarkan norma-norma sosial, pengetahuan dan kepentingan sendiri. Karena itu, strategi ini menyatakan bahwa untuk mempengaruhi perubahan sosial perlu terlebih dahulu mengubah nilai, sikap dan pemberian pengetahuan. Strategi paksaan-kekuasaan berasumsi bahwa manusia bertindak berdasarkan hubungan kekuasaan, baik yang sah maupun paksaan (Astiti 1994) .

Dalam sistem pemerintahan yang kaku dan totaliter, strategi untuk merekayasa perubahan sosial acapkali lebih mengandalkan pada strategi yang sifatnya koersif, yang berbasis pada kekuasaan dan ancaman sanksi yang sifatnya punitif. Sedangkan pada masyarakat yang demokratis seperti masyarakat Kota Surabaya, strategi yang dikembangkan seringkali merupakan perpaduan antara srategi yang pertama dan kedua. Intinya, di tengah kondisi di mana masyarakat makin kritis, maka upaya untuk merekayasa masyarakat tidak lagi bisa mengandalkan pada paksaan, melainkan harus lewat sosialisasi, pendekatan yang lebih bersifat bottom-up, menghargai prakarsa lokal, dan menempatkan masyarakat benar-benar sebagai subyek perubahan (Ever 1988).

Di berbagai negara, salah satu contoh strategi pembangunan yang menempatkan masyarakat sebagai subyek perubahan adalah apa yang dikenal dengan nama Pengembangan Komunitas, yakni pengembangan suatu proyek pembangunan di daerah atau komunitas yang menyertakan keterlibatan aktif para penduduknya. Yang dimaksud proyek pembangunan di sini adalah Program KB itu sendiri.

Pengalaman selama ini telah banyak mengajarkan bahwa untuk memastikan keberhasilan Program $\mathrm{KB}$, seringkali pemerintah harus berhadapan dengan berbagai dilema. Pertama, di era seperti sekarang ini -di mana masyarakat cenderung makin kritis- perlu disadari bahwa pemasyarakatan Program KB, pemerintah tidak lagi bisa hanya dengan mengandalkan pendekatan klinis yang sifatnya teknokratik dan top down. Kelemahan pendekatan klinis, meski jumlah klinik KB di kota besar seperti Surabaya dan Kabupaten Madiun relatif cukup banyak dan secara geografis mudah dijangkau, tetapi akses masyarakat dalam banyak hal relatif rendah, terutama masyarakat yang berasal dari golongan menengah ke bawah. 
Bagi masyarakat miskin, terutama harus diakui tidaklah mudah untuk mengakses program KB seperti Vasektomi, karena biaya yang tidak murah, dan membutuhkan kesiapan khusus (Rahardjo 1995). Kedua, di sisi yang lain, perlu disadari bahwa untuk menjamin kelangsungan keberhasilan Program $\mathrm{KB}$, pemerintah juga tidak mungkin hanya mengandalkan kepada pendekatan supply oriented dimana masyarakat didorong menggunakan kontrasepsi dengan cuma-cuma alias gratis, dan biasanya pemerintah melaksanakan pendekatan ini dengan didukung sistem target. Untuk jangka pendek, pendekatan supply oriented semacam ini memang biasanya efektif dan berhasil meraih partisipan KB dalam jumlah besar dan massal, namun pendekatan seperti ini tidak jarang dalam jangka panjang justru hanya menimbulkan ketergantungan, karena masyarakat sejak awal terbiasa diberi dan disubsidi dalam ber-KB.

Untuk mencapai efektivitas pelaksanaan Program KB di lapangan, yang dibutuhkan tentu saja bukan hanya perbaikan hal-hal yang sifatnya teknis-administratif, seperti meningkatkan kembali kegiatan sosialisasi manfaat Program KB, penegasan kewenangan pusat dan daerah dalam penanganan persoalan kependudukan atau menambah kembali jumlah petugas KB di lapangan. Hal yang lebih utama dan substansial sesungguhnya adalah berkaitan dengan upaya menumbuhkan kembali kesadaran, komitmen dan dukungan yang serius dari berbagai pihak untuk memahami pembangunan kualitas sumber daya manusia sebagai sebuah tahapan investasi bagi masa depan bangsa. Jika Program KB berjalan efektif, hasil akhir yang dicapai tidak hanya berupa terkendalinya pertumbuhan jumlah penduduk sesuai yang diharapkan, tetapi yang jauh lebih penting adalah terjadinya perbaikan derajat kesejahteraan masyarakat dan peningkatan kualitas sumber daya manusia yang mampu berperan aktif sebagai subyek pembangunan.

Salah satu program yang dikembangkan pemerintah untuk meningkatkan keberhasilan Program KB adalah melalui pemasyarakatan dan advokasi untuk mendorong keterlibatan kaum laki-laki dalam Program KB (Sureni et al. 1999). Dalam lima tahun terakhir, paling-tidak diketahui bahwa pendekatan Program KB telah berubah dari pendekatan pengendalian penduduk ke arah pendekatan kesehatan reproduksi yang lebih memperhatikan hak-hak reproduksi dan kesetaraan gender. Artinya, program KB kini tidak lagi hanya menjadi beban dan tanggung jawab perempuan, tetapi juga menjadi tanggungjawab kaum laki-laki (Mariyah 1989).

Pendekatan Program KB yang baru, menempatkan laki-laki sebagai partner reproduksi dan seksual yang setara bagi kaum perempuan, laki-laki terlibat langsung dalam fertilitas dan kebanyakan lakilaki adalah penanggung jawab sosial ekonomi keluarga (Hariastuti 2008). Laki-laki atau para suami, idealnya memang terlibat dan menjadi bagian penting dari upaya untuk mengendalikan pertumbuhan penduduk, merencanakan jumlah keluarga yang ideal dan bertanggungjawab terhadap kesejahteraan keluarganya. Namun dalam kenyataan harus diakui upaya untuk melibatkan peran aktif kaum lakilaki dalam ber-KB bukanlah sesuatu yang mudah.

Secara lebih rinci, sejumlah faktor yang menyebabkan pencapaian peserta KB Laki-laki di berbagai wilayah cenderung rendah adalah: Pertama, akses informasi sangat terbatas. Pengetahuan para laki-laki tentang kontrasepsi, seperti jenis, efek samping, efektivitas, cara penggunaan, tempat mendapatkan alat konrasepsi, manfaat dan lain-lain masih sangat rendah. Kedua, akses pelayanan masih terbatas. Belum semua suami atau kaum laki-laki mengetahui di mana tempat pelayanan MOP dilakukan, di samping ketersediaan dukungan jaringan pelayanan terhadap pelayanan KB laki-laki (vasektomi) masih terbatas pada tempat pelayanan tertentu. Ketiga, kondisi sosial budaya yang masih menghambat kaum laki-laki dalam Program KB, adanya anggapan masyarakat bahwa jika laki-laki menggunakan kontrasepsi itu dianggap tabu, menjadi bahan tertawaan, dan lakilaki yang ber-KB dianggap menderita penyakit tertentu seperti HIV-AIDS. Di kalangan sebagian ulama, tokoh masyaakat, dan juga di kalangan istri, tidak sedikit yang masih kurang atau bahkan tidak setuju keikutsertaan kaum laki-laki dalam Program KB, baik karena alasan agama maupun karena dinilai merupakan hal yang tabu. Beberapa alasan yang disampaikan oleh isri mengapa suami tidak diperbolehkan menggunakan metode vasektomi adalah dengan kontrasepsi yang mantap memungkinkan laki-laki untuk berselingkuh, sebab dengan vasektomi laki-laki tidak bisa menghamili 
lagi, atau potensi untuk melakukan hubungan seksual mengalami penurunan potensi seksualnya. Hal lain yang menjadi penyebab rendahnya partisipasi laki-laki ber-KB, rendahnya pengetahuan tentang tempat yang melayani laki-laki, karena sepengetahuan laki-laki banyak dokter kandungan atau bidan yang melayani KB untuk perempuan, sedangkan pada umumnya laki-laki tidak mengetahui dokter atau tenaga medis yang melayani KB untuk laki-laki. Selain itu, alat kontrasepsi yang disediakan pemerintah, sebagian besar adalah kontrasepsi yang khas untuk perempuan, seperti Pil, IUD, susuk, suntik, tubektomi yang selama ini merupakan kontrasepsi untuk perempuan, sehingga masyarakat khususnya laki-laki menganggap bahwa KB itu merupakan tanggung jawab perempuan, sementara kesejahteraan keluarga, merupakan tanggung jawab bersama suami dan istri.

Untuk meningkatkan peran dan keterlibatan kaum laki-laki dalam Program KB, saat ini kebijakan dan program yang dikembangkan diarahkan kepada: Pertama, peningkatan dukungan politis, sosialbudaya dan keluarga melalui kegiatan advokasi, promosi dan KIE secara intensif kepada para pengambil keputusan, TOMA/TOGA dan sasaran lain yang strategis termasuk anggota keluarga. Kedua, peningkatan intensitas dan kualitas pelayanan promosi dan konseling KB dan kesehatan reproduksi dengan penekanan tema sentral "laki-laki bertanggungjawab". Ketiga, peningkatan promosi dan konseling untuk meningkatkan pengetahuan dan kesadaran masalah kesetaraan dan keadilan gender. Keempat, peningkatan akses dan kualitas pelayanan bagi laki-laki untuk meningkatkan kesertaan dan partisipasi dalam KB dan kesehatan reproduksi.

\section{Simpulan}

Pertama, partisipasi laki-laki (suami) dalam ber-KB relatif masih rendah. Hal ini terlihat dari temuan studi ini, yaitu dari seluruh responden (laki-laki) sebanyak 10,67 persen yang menggunakan kontrasepsi berupa kondom dan 0,67 persen yang menggunakan kontrasepsi vasektomi, selebihnya perempuan (istri) yang menggunakan metode kontrasepsi. Banyak laki-laki yang memandang bahwa urusan KB adalah tanggung jawab perempuan. Meskipun demikian jika karena alasan kesehatan, misalnya perempuan tidak dimungkinkan menggunakan alat kontrasepsi, maka laki-laki akan menggunakannya.

Kedua, beberapa kendala yang menghambat partisipasi laki-laki dalam ber-KB adalah adanya kekhawatiran mengganggu kejantanan, impotensi, malu karena menjadi pergunjingan di masyarakat dan alasan ekonomi karena beranggapan bahwa vasektomi memerlukan biaya yang sangat tinggi, bahkan sejumlah laki-laki tidak mau melakukan vasektomi karena akan sulit ketika menginginkan anak lagi. Oleh karena itu, Pasangan Usia Subur (PUS) cenderung menggunakan kontrasepsi yang khas untuk perempuan, seperti pil, IUD, suntik dan susuk. Studi ini juga menemukan kendala yang menghambat partisipasi laki-laki dalam ber-KB justru datang dari istri, bahwa tidak sedikit istri (perempuan) yang tidak setuju apabila suaminya melakukan vasektomi. Alasan yang dikemukakan istri responden antara lain, bahwa vasektomi berisiko membuka peluang laki-laki selingkuh, dengan vasektomi dikhawatirkan laki-laki merasa lebih bebas, "aman-aman" jika melakukan perselingkuhan, karena tidak mungkin pasangan selingkuhnya hamil.

Di lingkungan masyarakat yang patriarkhis, pertimbangan yang rasional menjadi penting. Kesediaan responden pria untuk menggunakan metode kontrasepsi pria ternyata juga tidak terlepas dari pertimbangan rasional. Ada resiko atau tidak --baik terhadap isteri mau pun suami-- nampaknya menjadi dasar pertimbangan serius bagi kaum pria dalam memutuskan bersedia atau tidak untuk ber-KB. Artinya jika manfaat yang didapatkan responden ketika mereka menggunakan metode kontrasepsi dinilai lebih kuat bagi keluarga, maka mereka akan memiliki kemungkinan kuat pula untuk menggunakan metode kontrasepsi pria. Dalam hal ini faktor dampak terhadap kesehatan tubuh pasca penggunaan metode kontrasepsi tampaknya menjadi salah satu pertimbangan kuat mereka.

Ketiga, strategi yang perlu dikembangkan untuk meningkatkan partisipasi laki-laki dalam ber-KB antara lain adalah: 1) untuk mengurangi berbagai kekhawatiran suami maupun istri tentang risiko ber-KB Pria, khususnya vasektomi, perlu dilakukan sosialisasi yang lebih intensif, dan kampanye 
melalui media massa, yang menampilkan bintang iklan yang populer, sehingga keikutsertaan dalam Program KB Pria tidak lagi dianggap sebagai sesuatu yang tabu atau memalukan. Sosialisasi ini perlu dilakukan tidak hanya bagi kaum pria, tetapi juga bagi kaum perempuan, karena dalam kenyataan tidak jarang terjadi justru kaum perempuan sendiri yang menjadi penghalang kemungkinan suami mereka ikut serta dalam Program KB; 2) Untuk mempermudah akses para suami yang ingin melakukan vasektomi, ada baiknya jika dikembangkan berbagai pelatihan bagi para dokter atau tenaga medis lainnya dalam melakukan praktik vasektomi agar bisa dieliminasi sekecil-kecilnya kemungkinankemungkinan terjadinya kegagalan dan efek samping vasektomi yang tidak dikehendaki, sebab perasaan takut akan efek samping yang tidak diinginkan, secara langsung maupun tidak langsung akan menyebabkan partisipasi kaum pria dalam Program KB menjadi terhambat.

\section{Daftar Pustaka}

Astiti TIP (1994) Pengaruh hukum adat dan program keluarga berencana terhadap nilai anak laki-laki dan perempuan pada masyarakat yang sedang berubah. Disertasi, Institut Pertanian Bogor, Bogor.

BKKBN (2009) Faktor-faktor yang mempengaruhi rendahnya partisipasi laki-laki dalam KB. [Diakses 10 Agustus 2015]. http://www.bkkbn.go.id/gemalaki-laki/info-detail.php?infid=79,200.

BKKBN (2009) Problematika KB. [Diakses 1 Juli 2009]. http://www.bkkbn.go.id.artikel//23455/566. php.

Chin R \& Benne KD (1969) General Strategies for Effecting Changes in Human Systems. In: WG Bennis, KD Benne, \& R Chin (eds). The Planning of Change, New York: Holt, Rinehart \& Winston.

Ever Hans-Dieter (Peny.) (1988) Teori Masyarakat: Proses Peradaban dalam Sistem Dunia Modern. Jakarta: Yayasan Obor Indonesia.

Hariastuti I (2000) Analisis kualitas pelayanan KB di Kabupaten Purworejo. Tesis, Universitas Gadjah Mada, Yogyakarta.

Hariastuti I (2008) Strategi pembangunan KB berbasis masyarakat sebagai upaya pembangunan Keluarga Berencana di Jawa Timur. [Diakses 15 Juni 2015]. https://jurnal.ugm.ac.id/.

Ibrahim IS (2005) Budaya Populer Sebagai Komunikasi, Dinamika Popscape dan Mediascape di Indonesia Kontemporer. Yogyakarta: Jalasutra.

Kee WF \& Lee AS (1973) Studies in Family Planning in Taiwan. [Diakses 26 Juli 2015]. https:// www.ncbi.nlm.nih.gov/pubmed/4710480.

Mariyah E (1989) Faktor-faktor yang mempengaruhi penerimaan kontrasepsi pada masyarakat Jawa Timur. Tesis, Universitas Gadjah Mada, Yogyakarta.

Ritya G (2009) KB Aktif Belum Capai 70 Persen dari Total Pasangan Usia Subur. [Diakses 28 Maret 2014]. http://hierobokilia.blogspot.com/2009/04/kb-aktif-belum-capai-70-persen-dari.html.

Rahardjo S (1995) Panduan Pelayanan Vasektomi Tanpa Pisau. Jakarta: PKMI.

Sriudayani IA (2003) Peran Perempuan dalam pengambilan Keputusan di Dalam Keluarga Untuk Bidang KB-KR. Jakarta: Lembaga Puslitbang Ks-PKP BKKBN. [Diakses 1 Juli 2009]. www. pikas.bkkbn.go.id/ditfor/research detail.php.

Sureni (1999) Studi Gender Peranan Laki-laki dalam Penggunaan Kontrasepsi di Propinsi DIY. Yogyakarta: Kanwil BKKBN \& PSW UMY.

Winarni E (2005) Partisipasi Laki-laki dalam ber-KB ( Sumber data : SDKI 2002-2003); Jakarta, Lembaga Puslitbang KB-KR BKKBN.

Wetson (2002) Para Perempuan Mempercayai Pasangan untuk Menggunakan Kontrasepsi Laki-laki. [Diakses 15 Juli 2015]. http://pikas.bkkbn.go.id. 24 Ibid.

Wetson (2008) Panduan Peningkatan Partisipasi Laki-laki dalam Ber-KB. Jakarta: Direktorat Peningkatan Partisipasi Laki-laki, Badan Koordinasi Keluarga Berencana Nasional.

Yen CH \& Wang CM (1973) Studies in Family Planning in Taiwan. [Diakses 25 November 2014]. https://www.ncbi.nlm.nih.gov/labs/articles/4710481. 